\title{
GAMBARAN ASUPAN KALORI PADA KLIEN DIABETES MELLITUS TIPE 2 DI RW 05 KELURAHAN SAWUNGGALING KECAMATAN WONOKROMO SURABAYA
}

\author{
Sisilia Indriasari W.*, Christina Laurensia Manuel** \\ *STIKES Katolik St. Vincentius a Paulo Surabaya \\ e-mail: sisil_indri@yahoo.co.id
}

\begin{abstract}
ABSTRAK
Klien diabetes mellitus tipe 2 harus menjaga berat badan dengan memperhatikan jumlah kalori yang dikonsumsi tiap harinya, dan penurunan berat badan sudah terbukti dapat meningkatkan kontrol diabetes. Peneliti mengamati fenomena di RW 05 Kelurahan Sawunggaling Kecamatan Wonokromo Surabaya, klien diabetes mellitus mengatakan setiap hari tidak membatasi jumlah makanan yang dimakan. Tujuan penelitian untuk mengidentifikasi gambaran asupan kalori pada klien diabetes mellitus tipe 2 di RW 05 Kelurahan Sawunggaling Kecamatan Wonokromo Surabaya. Desain penelitian yang digunakan yaitu deskriptif dengan variabelnya asupan kalori pada klien diabetes mellitus tipe 2 di RW 05 Kelurahan Sawunggaling Kecamatan Wonokromo Surabaya. Populasi dalam penelitian ini, semua klien diabetes mellitus tipe 2 di RW 05 Kelurahan Sawunggling Kecamatan Wonokromo Surabaya dengan kriteria inklusi bersedia menjadi responden dan mengikuti posyandu lansia. Teknik sampling menggunakan simple random sampling dan diperoleh besar sampel sebanyak 44 responden. Instrumen pengumpulan data berupa formulir food recall 24 jam kemudian dianalisis dengan menggunakan rumus analisa statistik deskriptif proporsi prosentase. Hasil dari penelitian menunjukkan bahwa sebanyak $80 \%$ pasien diabetes mellitus asupan kalorinya tidak sesuai dengan IMT dan aktivitas sehari-hari. Peneliti memberi saran agar kader kesehatan RW 05 Kelurahan Sawunggling Kecamatan Wonokromo Surabaya bekerja sama dengan ahli gizi bagian perbaikan gizi masyarakat Puskesmas Jagir untuk memberikan penyuluhan perindividu klien diabetes yang ada di RW 05 Kelurahan Sawunggaling Kecamatan Wonokromo tentang perhitungan kalori yang tepat, dan bagi klien diabetes mellitus untuk membuat catatan khusus pada buku harian untuk pemenuhan jumlah kalori yang tepat tiap harinya.
\end{abstract}

Kata Kunci : Diabetes Mellitus Tipe 2, Asupan Kalori, Indeks Massa Tubuh.

\section{ABTRACT}

Clients of type 2 diabetes mellitus should maintain their weight with respect to the number of calories consumed each day, and weight loss has proven to keep diabetes under control. Researcher observed a phenomenon in RW 05, Kelurahan Sawunggaling, Wonokromo District,Surabaya, where clients of type 2 diabetes mellitus claimed that they did not limit their amount of food eaten. The aim of this research was to identify the description of the calorie intake on those clients in that area. The design of this research applied a descriptive research design with the variable of the caloric intake on those clients. The population in this research was all of those clients in the area willing to berespondents with inclusion criteria and follow the Integrated Health Post/ Posyandu. The sampling technique was a simple random sampling obtaining a sample size of 44 respondents. The instrument for data collection was forms of a 24-hour food recall which was later analyzed using descriptive statistical analysis formulas of percentage and proportions. Results from the study showed that as many as $80 \%$ of them was with the calorie intake not complying with their BMI and daily activities. Researcher suggests that health workers of that area cooperate with nutritionists of department of improving nutrition community at Public Health Center/ Puskesmas Jagir. That is to provide counseling and distribute leaflets about the correct calculation of calories according to BMI and activities conducted by those clients. They were also asked to make a special note in their diary for fulfilling the right amount of calories for each day.

Keywords: Diabetes Mellitus Type 2, Calorie Intake, Body Mass Index. 


\section{Pendahuluan}

Kalori pada pasien diabetes mellitus mempengaruhi berat badan (Barnes, 2012, hal: 84). Kebanyakan penderita diabetes mellitus tipe II mempunyai berat badan lebih dari normal (Arisman, 2011, hal: 52). Biasanya dengan menurunkan berat badan dapat memperbaiki kerja insulin dan menurunkan glukosa darah (Soegondo, 2009, hal: 38). Menurut Prayugo (2012), didapatkan bahwa ada hubungan yang kuat antara pola diit tepat jumlah dengan kadar gula darah puasa pasien diabetes mellius II dibandingkan dengan diit tepat jadwal. Salah satu faktor resiko penyebab diabetes mellitus tipe II adalah obesitas (Hasdianah, 2012, hal: 18), untuk itu pasien diabetes mellitus tipe II harus menjaga berat badan dengan memperhatikan jumlah kalori yang dikonsumsi tiap harinya, dan penurunan berat badan sudah terbukti dapat meningkatkan kontrol diabetes (Waspadji, 2009, hal: 50).

Proporsi dan perkiraan jumlah penduduk usia $\geq 15$ tahun yang terdiagnosis dan merasakan gejala diabetes mellitus di Jawa timur Timur tahun 2013 menurut Kementrian Kesehatan RI (2013) adalah 28.855.895 jiwaSatu bulan terakhir mengalami gejala sering lapar, sering haus, sering buang air kecil dengan jumlah banyak dan berat badan turun sekitar 115.424 jiwa. Dari hasil wawancara 10 klien diabetes mellitus yang ada di RW 05 Kelurahan Sawunggaling Kecamatan Wonokromo Surabaya tanggal 23 november 2015, didapatkan semua penderita memiliki penyakit penyerta lainnya seperti hipertensi dan kolesterol serta tidak pernah melakukan diet apapun dan porsi makan tiap harinya tidak pernah di hitung. Prinsip pengaturan makan pada penyandang diabetes yaitu makanan yang seimbang, sesuai dengan kebutuhan kalori masing-masing individu dengan memperhatikan keteraturan jadwal makan, jenis dan jumlah makanan. Jadwal makan bagi penderita diabetes biasanya 6 kali makan, yaitu 3 kali makan besar dan 3 kali selingan. Prinsip jumlah makanan yang dianjurkan untuk penderita diabetes mellitus adalah porsi kecil dan sering. Jenis makanan menentukan kecepatan naiknya kadar gula darah, jadi hindari makanan yang berindeks glikemik tinggi seperti sumber karbohidrat sederhana, gula, madu, sirup, roti, dll.
Tujuan penelitian Mengidentifikasi gambaran Asupan kalori pada klien diabetes mellitus tipe 2 di RW 05 Kelurahan Sawunggaling Kecamatan Wonokromo Surabaya

\section{Metode}

Penelitian ini menggunakan desain deskriptif dengan variabel menggunakan variabel tunggal yakni asupan kalori pada klien diabetes mellitus tipe 2. Populasi dalam penelitian ini adalah semua klien diabetes mellitus tipe 2 yang ada di RW 05 Kelurahan Sawunggaling Kecamatan Wonokromo Surabaya dengan kriteria inklusi bersedia menjadi responden dan mengikuti posyandu lansia. Besar sampel dalam penelitian ini adalah 44 reesponden dengan metode sampling yang digunakan adalah teknik simple random sampling. Pengumpulan sampling dilaksanakan pada tanggal 19 Mei21 Mei 2016. Pengumpulan data menggunakan formulir food recall 24 jam, dari hasil food recall maka data asupan makanan responden akan dikategorikan sesuai dan tidak sesuai. Data yang terkumpul kemudian diolah dan selanjutnya dilakukan analisis menggunakan rumus Analisis Statistik Deskriptif Propoorsi Prosentase.

\section{Hasil}

Tabel 1 Karakteristik Responden

\begin{tabular}{lll}
\hline Variabel & $\begin{array}{l}\text { Frekuensi } \\
(\mathrm{n})\end{array}$ & $\begin{array}{l}\text { Presentase } \\
(\%)\end{array}$ \\
\hline $\begin{array}{l}\text { Usia } \\
45-59\end{array}$ & 13 & 30 \\
$60-74$ & 27 & 61 \\
$75-90$ & 4 & 9 \\
$\begin{array}{l}\text { Penyakit } \\
\text { Penyerta }\end{array}$ & & \\
$\begin{array}{l}\text { Kolesterol } \\
\text { Katarak }\end{array}$ & 5 & 11 \\
hipertensi & 17 & 7 \\
tidak ada & 19 & 39 \\
penyakit \\
penyerta
\end{tabular}




\begin{tabular}{lll} 
Ringan & 15 & 34 \\
Sedang & 26 & 59 \\
Berat & 3 & 7 \\
\hline
\end{tabular}

Dari tabel di atas didapatkan hasil menurut usia yaitu $27(61 \%)$ responden berusia 60-74 tahun. Berdasarkan adanya komplikasi didapatkan 19 (43\%) responden tidak memiliki penyakit penyerta. Berdasarkan IMT terdapat $26 \quad(59 \%)$ responden dengan berat badan lebih $>23$. Berdasarkan aktivitas sehari-hari terdapat 26 $(59 \%)$ responden dengan aktivitas sedang.

\section{Tabel 2. Asupan Kalori Klien Diabetes} Mellitus Tipe 2

\begin{tabular}{lll}
\hline $\begin{array}{l}\text { Asupan } \\
\text { Kalori }\end{array}$ & Frekuensi (n) & $\begin{array}{l}\text { Prosentase } \\
(\%)\end{array}$ \\
\hline Sesuai & 35 & 20 \\
Tidak & 9 & 80 \\
Sesuai & & \\
\hline
\end{tabular}

Berdasarkan tabel diatas responden yang asupan kalorinya tidak sesuai lebih banyak dibandingkan dengan responden yang asupannya sesuai.

\section{Pembahasan}

Berdasarkan hasil penelitian didapatkan data bahwa dari 44 responden terdapat sebanyak 35 responden $(80 \%)$ yang asupan kalorinya tidak sesuai dan 9 responden (20\%) asupan kalorinya sesuai. Berdasarkan dari indeks massa tubuh didapatkan hasil 23 responden dengan berat badan lebih. Berdasarkan pernah atau tidak pernah mendapatkan informasi tentang asupan kalori didapatkan hasil 35 responden tidak pernah mendapatkan informasi tentang perhitungan kalori. Menurut Dwijayanthi (2011) berat badan lebih disebabkan oleh ketidakseimbangan energi yang timbul bila jumlah asupan kalori melebihi jumlah kalori yang digunakan untuk menghasilkan energi. Ketidakseimbangan yang terjadi terus menerus membuat berat badan senantiasa bertambah, yang disebabkan oleh perilaku makan berlebih, kurang beraktivitas atau keduanya. Pada klien dengan berat badan lebih asupan energi harus lebih rendah dari keluaran energi untuk menciptakan keseimbangan negatif, yang menghasilkan penurunan berat badan. Menurut Suyono (2009) penurunan berat badan dan hipokalori biasanya memperbaiki kadar glikemik jangka pendek dan mempunyai potensi meningkatkan kontrol metabolik jangka lama, dengan asupan kalori yang dikonsumsi sesuai dengan IMT, mampu menunda terjadi komplikasi akut maupun kronis. Peneliti berpendapat bahwa ada kesesuaian antara fakta dan teori, dimana pada klien diabetes mellitus sebagian besar asupan kalori yang dikonsumsi tiap hari tidak sesuai dengan IMT dan aktivitas sehari-hari. Asupan kalori yang tidak sesuai bisa disebabkan karena prinsip pengaturan makan yang tidak tepat. Prinsip pengaturan makan yang tepat pada penyandang diabetes yaitu makanan seimbang, sesuai dengan kebutuhan kalori masing-masing individu dengan memperhatikan keteraturan jadwal makan, jenis dan jumlah makanan. Klien diabetes mellitus pasti menjalani diet seumur hidup untuk mengontrol kadar glukosa darah. Diet seumur hidup sering membuat klien merasa bosan, sehingga bisa menjadi salah satu penyebab asupan kalori yang dikonsumsi tidak sesuai. Penyuluhan juga menjadi salah satu yang bisa menyebabkan asupan kalori pada klien diabetes mellitus tidak sesuai, dengan meningkatkan pengetahuan diabetisi tentang pengelolaan penyakitnya, dapat mencegah komplikasi lebih lanjut. Asupan kalori yang berlebihan pada klien diabetes mellitus di RW 05 Kelurahan Sawunggaling Kecamatan Wonokromo Surabaya ini bisa jadi disebabkan karena responden hanya baru mendapatkan penyuluhan tentang diet diabetes mellitus secara umum namun untuk penyuluhan secara individu belum pernah dilakukan.

\section{Simpulan dan Saran}

Mayoritas responden (80\%) asupan kalorinya tidak sesuai dengan IMT dan aktivitas sehari-hari pada klien diabetes mellitus tipe 2 .

Berdasarkan hasil penelitian, sebagian besar responden asupan kalorinya tidak sesuai maka solusi yang bisa peneliti tawarkan adalah kader kesehatan RW 05 Kelurahan Sawunggling Kecamatan Wonokromo Surabaya bekerja sama dengan ahli gizi bagian perbaikan gizi masyarakat Puskesmas Jagir untuk memberikan penyuluhan dan membagikan leaflet tentang 
perhitungan kalori yang benar tiap harinya sesuai IMT dan aktivitas yang dilakukan klien diabetes yang ada di RW 05 Kelurahan Sawunggaling Kecamatan Wonokromo, dan bagi klien diabetes mellitus untuk membuat catatan khusus pada buku harian untuk pemenuhan jumlah kalori yang tepat tiap harinya.

\section{Daftar Pustaka}

Almatsier, S. (2006). Penuntun Diet. Jakarta: Gramedia Pustaka Utama

Arisman. (2011). Obesitas, Diabetes Mellitus \& Dislipidemia. Jakarta: EGC

Barasi, M. E. (2007). Nutrion at a Glance. Alih Bahasa: Halim, H. 2009. Jakarta: Erlangga

Barners, D.F. (2012). Program Olahraga : Diabetes. Yogyakarta: Intan Sejati

Buckman \& Robert. (2009). Apa yang Seharusnya Anda Ketahui Tentang Stroke. Yogyakarta: Intan Sejati

Depkes RI. (2013). Riset Kesehatan Dasar. Jakarta: Badan Penelitian \& PengembanganKesehatan Kementrian Kesehatan RI

Dwijayanthi, L. (2011). Ilmu Gizi Menjadi Sangat Mudah Edisi 2. Jakarta: EGC

Fatmah. (2010). Gizi Usia Lanjut. Jakarta: Erlangga

Gibney. dkk (2009). Gizi Kesehatan Masyarakat.Jakarta: EGC

Hartono, A. (2006). Terapi Gizi dan Diet Rumah Sakit Edisi 2. Jakarta: EGC

Hasdianah. (2012). Mengenal Diabetes Mellitus. Yogyakarta: Nuha Medika

Hidayat, A. A. (2010). Metode Penelitian Kesehatan Paradigma Kuantitatif. Jakarta: Heath Books (2009). Metode Penelitian Keperawatan dan Teknik Analisa Data. Jakarta: Salemba Medika (2007). Riset Keperawatan \& Teknik Penulisan Ilmiah. Jakarta: Salemba Medika

Info Diabetes Mellitus. (2012). Pola Makan $3 J$ Untuk Penderita Diabetes. Diakses 26 Januari 2016 dari http://indodiabetes.com/pola-makan3j-untuk-penderita-diabetes.html

Mahendra. dkk. (2008). Care Your Self Diabetes Mellitus.Jakarta: Plus
Mann, J. \& Stewart, T. (2012). Buku Ajar Ilmu Gizi Edisi 4. Alih Bahasa: Rachmat, M. 2014. Jakarta: EGC

Mansjoer, A. (2008). Kapita Selekta Kedokteran. Jakarta: Media Aesculapius

Moyet, L. J. C. (2003). Buku Saku Diagnosa Keperawatan Edisi 10. Alih Bahasa: Asih, Y. 2007. Jakarta: EGC

Nazir, M. (2011). Metode Penelitian. Bogor: Ghalia Indonesia

Notoatmodjo, S. (2012). Promosi Kesehatan dan Perilaku Kesehatan. Jakarta: Rineka Cipta

Nursalam. (2013). Metodologi Penelitian Ilmu Keperrawatan.Jakarta: Salemba Medika

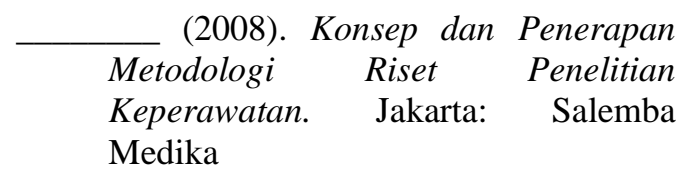

Persatuan Endokrinologi Indonesia. (2011). Konsensus Pengelolaan \& Pencegahan Diabetes Mellitus Tipe 2 di Indonesia 2011.Jakarta: PERKENI

Prasetyono, D. (2012). Daftar Tanda \& Gejala Ragam Penyakit. Yogyakarta: Flash Books

Price, S. A \& Wilson, L. M. (2006). Patofisiologi Konsep Klinis ProsesProses Penyakit Edisi 6. Jakarta: EGC

Purwanto, H. (1994). Pengantar Statistik Keperawatan.Jakarta: EGC

Prayugo, P. J. S. (2012). Patternn Right Amount Diet, Schedule, and The Blood Sugar of Patients with Diabetes Mellitus Installation of Type II In Out Patient.Diakses dari https://www.google.com/url?sa=t\&rct $=\mathrm{j} \& \mathrm{q}=\&$ esrc $=\mathrm{s} \&$ source $=$ web $\& \mathrm{~cd}=1 \& \mathrm{c}$ ad=rja\&uact $=8 \& v e d=0$ ahUKEwjf 8979

Sari, N. S. (2012). Diabetes Millitus. Yogyakarta: Nuha Medika

Setiadi. (2013). Konsep dan Penulisan Riset Keperawatan.Yogyakarta: Graha Ilmu

Sugiyono. (2013). Metode Penelitian Pendidikan (Pendekatan Kuantitatif, Kualitatif dan $R \& D$ ).Bandung: Alfabeta

Supariasa., Bakri., Fajar. (2012). Penilaian Status Gizi. Jakarta: EGC

Suyono, S. (2009). Diabetes Mellitus di Indonesia Buku Ajar Ilmu Penyakit Dalam. Jakarta: Interna Publishing 
Soegondo, S. (2008). Diabetes Melitus Kencing Manis Sakit Gula.Jakarta: Balai Penerbit FKUI

Waspadji, S., Sukardji, K., Octarina, M. (2009). Pedoman Diet Diabetes Mellitus.Jakarta: FKUI

Winarti, S. (2010). Makanan Fungsional. Surabaya: Graha Ilmu

Yunir. (2011). Terapi Non Farmakologis pada Diabetes Mellitus. Jakarta: FKMUI 